\title{
The Importance of Ethics in Branding: Mediating Effects of Ethical Branding on Company Reputation and Brand Loyalty
}

Sharifah Faridah Syed Alwi, Brunel University London

Sulaiman Muhammad Ali, University of Syiah Kuala

Bang Nguyen, University of Science and Technology

\begin{abstract}
This study aims to develop an ethical branding framework that determines whether a corporate brand's functional and emotional values, that is, product, service quality and perceived price (antecedents), influence ethical branding, and, consequently, company reputation and brand loyalty (consequences) among industrial buyers of electronic office equipment in Malaysia. Using structural equation modelling, the paper demonstrates the effects of perceived price, quality of product and service on ethical branding, company reputation and brand loyalty. The results reveal that product quality directly influences ethical brand perceptions, and, consequently, company reputation. Perceived price and service quality do not directly affect company reputation; instead, they affect its identification through ethical branding. The findings thus demonstrate that product quality, perceived price, and service quality affect company reputation through the mediation of ethical branding. This highlights that an ethical brand is effective for companies to maintain their reputation among industrial buyers.
\end{abstract}

KEYWORDS: Ethics, ethical branding, ethical corporate marketing, corporate brand, corporate reputation and electronic office equipment. 


\section{INTRODUCTION}

With the complexity of the modern business world, developing a corporate brand continues to be a major challenge (Melewar \& Nguyen, 2015). Companies today are expected to deliver more value as well as behave responsibly and ethically toward their stakeholders (Martin \& Johnson, 2010; Olin, 2014). Both consumers and investors are increasingly aware of socially irresponsible behavior by some companies (Mulki \& Jaramillo, 2011), which constitutes an emerging issue that must be addressed (Balmer, Powell \& Greyser, 2011). In response to these developments, several scholars (Balmer et al., 2011; Okoye, 2009; Powell, 2011; van de Ven, 2008) have proposed that organizations must balance their relationship between making money and doing the right thing via an "ethical brand identity".

The ethical brand identity is a concept in which the corporation is a citizen of a society with rights and responsibilities (Andriof \& McIntosh, 2001; Okoye, 2009). It is an approach to positioning and differentiating a brand that starts from the root of the company and is heavily influenced by ethical principles and the concept of corporate social responsibility (CSR) (Biraghi \& Gambetti, 2015). CSR is a form of corporate self-regulation integrated into a business model (McWilliams \& Siegel, 2001). The key notion of ethical brand identity is that managers must comprehend that branding should be addressed from the root or essence of the organization (i.e., getting it right from the beginning), starting with its values, mission and vision, which, in turn, shape its corporate strategy (Balmer et al., 2011; Biraghi \& Gambetti, 2015; Hur, Kim \& Woo, 2014; McWilliams \& Siegel, 2001; Olin, 2014; Okoye, 2009; Powell, 2011; Urde, Baumgarth \& Merrilees, 2013; Votaw, 1972). Hence, it can be appropriate to define the ethical brand identity using both ethical principles, and CSR values

and dimensions (e.g., economic, environment and social responsibility) ${ }^{1}$ (Fan, 2005; van de Ven, 2008). Once an ethical brand identity is established, it will help to remind the organization of its essence and stance, its promises and agreements, and, thus, subsequent 
marketing activities will be created according to these values. Therefore, ensuring an ethical focus from the beginning with the roots driven into CSR-influenced values is important to every organization. By incorporating an ethical philosophy through CSR elements in their strategic corporate marketing approach, such as when designing their mission and vision, organizations can enhance their identities (Balmer et al., 2011). This CSR approach thus fuels the ethical brand identity concept in the way that a firm can use CSR elements to shape its identity and place importance on an identity-driven approach in which the identity is formed from the inside out (Balmer, 2013; Urde, 2009; Urde et al., 2013). Thus, the "CSR-identity"approach serves as the starting point of an organization's positioning concerning what it stands for, and thereby defines the essence of the corporation (Urde et al., 2013). This marks a new approach to projecting a corporate identity (Singh, Iglesias \& Batista-Foguet, 2012; van Rekom, Go \& Calter, 2014) and how an organization can potentially sustain its brand for a long-term competitive advantage (Carroll \& Buchholtz, 2014; Mulki \& Jaramillo, 2011).

This kind of conceptual and empirical understanding of how a company can utilize corporate marketing/branding and CSR, as well as be considered an ethical brand, and the company's relationship with marketing strategy or corporate marketing outcomes (such as corporate reputation, brand loyalty, and brand equity), however, is still rare (Balmer et al., 2011; Brunk, 2010; Hur, Kim \& Woo, 2014; Mulki \& Jaramillo, 2011; Powell, 2011; Singh et al., 2012). The theoretical gaps comprise four different points. (1) Although CSR is not new in the business ethics literature and is widely researched, its empirical relationship in shaping corporate brand identity and linkage to marketing strategy is still uncommon (Hur et al., 2014; Loe et al., 2000; Mulki \& Jaramillo, 2011). (2) Most CSR research centers on the topic of its effectiveness and its outcome rather than its empirical relationship with (corporate) marketing outcomes (e.g., brand equity, consumer attitudes and consumer loyalty) (Brunk, 2012; Hur et al., 2014). (3) A new stream of research has emerged that links 
CSR to marketing outcomes; however, this research predominantly examines the product level (e.g., Brunk, 2010; 2011; Singh et al., 2012) with the exception of Hur et al. (2014), whose research focuses on the corporate brand level. As argued, addressing CSR at the product level cannot address a company's ethical stance through its corporate philosophy and identity, and thus, countless stakeholders, who must be the focus when communicating CSR, cannot be reached. (4) Finally, most of the research focuses on the relationship between CSR and brand equity targets consumers (rather than the industrial buyer) (Brunk, 2010b; Palazzo \& Basu, 2007; van de Ven, 2008), with the exception of Chi-Shiun, Chih-Jen, Chin-Fang and Da-Chang (2010). Hence, the effect of CSR on corporate branding outcomes among industrial buyers is underemphasized since previous research concerning the purchase decision-making of organizations primarily focuses on the individual factors of employees or organizational factors (Loe et al., 2000; van de Ven, 2008).

To fill the above gaps, this study investigates what makes a company's identity visible as an "ethical brand" through positioning its identity in a more strategic manner. While previous studies provide useful reasons for why marketing strategies should explicitly incorporate CSR dimensions to ensure that the company is considered an ethical brand, as well as why CSR should be the main focus of the company's brand positioning, how this is to be achieved (guidelines) is not discussed as the previous works are largely conceptual (van de Ven, 2008) and at the rhetoric level (Parguel, Benoit-Moreau \& Larceneux, 2011). These perspectives limit the understanding of how a company can enhance its position as an ethical brand and whether this condition then influences its company reputation, and, consequently, brand loyalty. Additionally, understanding how customers form the concept of an ethical brand allows deeper insights into their responses to corporate ethics, CSR or corporate reputation (Brunk, 2010b). 
We therefore approach this question by extending these conceptual papers through an empirical validation of how a company can enhance its identity through ethical branding (incorporating the CSR elements) with a different stakeholder approach: business buyers. In particular, the earlier research lacks empirical guidance regarding (1) how one should define and measure ethical branding at the corporate level; (2) what makes a company visible as ethical; and (3) its impact among business buyers on corporate marketing outcomes, such as company reputation and brand loyalty. The study combines several business domains to express its originality, that is, by incorporating CSR from the business ethics literature into the corporate brand and the corporate marketing domain. Particularly, it empirically investigates how an ethical brand is formed, how to operationalize and measure the concept, and its relationship (as a mediator construct) with corporate marketing outcomes (corporate or company reputation and brand loyalty) among business buyers. Studying industrial buyers of electronic products (the focus of this study) is particularly important in that the increasing awareness of environmental issues has stimulated concern about the disposal of products containing hazardous waste and the associated deleterious effects on the quality of the environment (Nnorom \& Osibanjo, 2008). These ethical issues affect every type of business, enterprise, organization and person (Sharp, 2003); thus, making our research into the ethical brand concept both timely and crucial.

The remainder of the paper is organized as follows. First, we elaborate on the research background in relation to the marketing and brand ethics literature, and develop a series of research hypotheses. Subsequently, we present our method in detail, followed by our study results. We then discuss our findings and contributions. Finally, we consider the study's implications for management and recommend suggestions for future research.

\section{LITERATURE REVIEW AND HYPOTHESES DEVELOPMENT}

Ethical branding - What is it? 
We approach our ethical branding definition by examining the literature pertaining to two domains: (1) business ethics and CSR, and (2) marketing ethics (in particular, societal marketing, ethical corporate marketing and branding). Ethics in marketing and branding is the most difficult concept to define, as, to date, how best to conceptualize, operationalize and measure ethics has been a challenge (Brunk, 2012; Fan, 2005; Maignan, Ferrell \& Ferrell, 2005; Singh et al., 2012). Our definition of an ethical brand is guided by the following three bases: (1) ethics in marketing and branding (through CSR dimensions); (2) the chosen stakeholders - industrial buyers; and (3) the context under study - electrical and electronic products.

A corporation's corporate image is vital for businesses to elicit a stronger positive emotional response from its stakeholders/society, and to help enhance its business performance, corporate brand equity (Hur et al., 2014; Stanaland, Lwin \& Murphy, 2011) and corporate sustainability (Carroll, 2000; Powell, 2011). Incorporating CSR elements at the early stages of designing a company's corporate strategy not only contributes to how the mission and vision of the company could be written around this philosophy but also encourages companies to exert effort to achieve a positive image and reputation built around sincerity, integrity and honesty (Balmer et al., 2011; Hur et al., 2014; van de Ven, 2008). Additionally, since the corporate marketing era, the ethical and CSR terms have been emphasized in the shape of the philosophy, as provided in the following definition:

Corporate marketing is a customer, stakeholder, societal and CSR focused philosophy enacted via an organization-wide orientation and culture. A corporate marketing rational complements the goods and services logic. It is informed by identity-based views of the firm: this is a perspective which accords importance to corporate identities and corporate brands. The latter provide distinctive platforms from which multi-lateral, organizational and stakeholder/societal relationship are fostered to all-round advantage. The corporate marketing orientations are also mindful of its corporate responsibilities in societal, ethical and CSR terms (Balmer, 2011:1350).

The marketing domain, having begun with a production and selling orientation, later progressed to a marketing, brand and societal orientation in which consumers constitute the 
focal point. From 1995 onwards, however, corporate marketing and corporate brand have been introduced (Balmer, 1995). This indicates that while the marketing orientation has been useful, with the technological explosion, crisis and reputation management, and the changing business landscape (business transparency), it is not only necessary to address consumers but also multiple stakeholders by building corporate brand identity, corporate image and corporate reputation. In addition, addressing these issues to innumerable stakeholders has become more important, which product values alone cannot address. These elements corporate identity, corporate image, corporate brand, corporate communication and corporate reputation - are the main mix of corporate marketing, and addressing the higher or corporate level extends the elements of the previous orientation of marketing (the marketing mix/4Ps), which pertain only to the product level (Balmer \& Greyser, 2006). Corporate brand thus represents the total brand promise of the company, includes both product and company values, and represents not only the values from within the company (philosophy, culture, identity) but also what it communicates externally to its stakeholders (image and reputation) (Balmer, 2011). Thus, in line with earlier studies (Balmer, 1995; Balmer, 2001; Balmer, 2013; Beren et al., 2011; Beren \& van Riel, 2005; Biraghi \& Gambetti, 2015; Olin, 2014; Powell, 2011; Urde et al., 2013; Urde, 2003; Urde, 2009; van de Ven, 2008; Xie \& Boggs, 2006), this study adopts the corporate marketing approach in developing the study's conceptual model and later tests it empirically.

Hence, to address the complexity of addressing other stakeholders, such as at the industrial level, seeing that a corporation behaves morally and undertakes its social responsibility encourages stakeholders to enhance a firm's positive image and reputation among its suppliers (Brunk, 2010; Palazzo \& Basu, 2007), as well as the commitment to the corporation (Balmer, 2013; Davies, Chun, da Silva \& Roper, 2004; Olin, 2014; van de Ven, 2008). 
Additionally, the core element of a corporate brand, which is shaped through corporate identity, includes products, services, its citizenship program and its corporate social responsibility program (Abratt \& Kleyn, 2012). In addition, corporate brand is formed through what Brown and Dacin (1997), and Dacin and Brown (2002) refer to as corporate associations. These associations include the company's products and services, which represent an important characteristic when relating to the consequences or marketing outcomes, such as product responses (i.e., product perceptions or evaluations, purchase intentions , purchase behaviors) and responses to the company (i.e., trust and commitment) (Brown, 1998).

From a stakeholder's perspective, ethical branding is about delivering the company's responsibility and its moral obligation to them/society (Maignan et al., 2005). Maignan et al. (2005) explain that practitioners and marketers struggle with the notion of corporate social responsibilities and the meaning of the word society as it is a very abstract concept that is more ambiguous than a corporation (Clarkson, 1995). Hence, researchers must be more specific regarding which stakeholders corporations currently interact with, and then define corporations' ethical branding based on the moral responsibilities the companies have toward their stakeholders (Maignan et al., 2005). Therefore, the organization's CSR efforts are issuespecific, and the organization could focus on improving its exemplary behavior with respect to one context and/or stakeholder (Maignan et al., 2005).

Additionally, organizations employ several means to form the core values or philosophy behind the corporate ethical branding, such as values derived from: (1) organization; (2) product/service brand; and (3) added value as they are experienced by customers (Urde, 2003), particularly among industrial buyers (Beverland, Napoli \& Yakimova, 2007).

Balmer et al. (2011) explain that ethical identity from a corporate marketing perspective should have explicit CSR dimensions that address such moral obligations. In 
particular, these moral obligations include attributes, such as economic criteria, honesty, integrity, diversity, responsibility, quality, respect, accountability and not harming the public good. Instead, corporations should contribute to or help promote public good (Fan, 2005). In a similar vein, Singh et al. (2012) define ethical brand as the perception of a brand that reflects honesty, responsibility and accountability toward various stakeholders. Bhattacharya and Sen (2004) add that the main objective of CSR is to be seen to embody ethical values and respect people, communities and the natural environment. Several scholars in marketing and branding (Brunk, 2010; 2012; Enderle \& Tavis, 1998; Hur et al., 2014; Singh et al., 2012) propose that a firm could address its responsibility through economic, social and environmental dimensions to achieve corporate sustainability. For example, economic responsibility refers to activities that are intended to maximize the company's profit and economic impact, (maximization of share value), while simultaneously improving employees' morale/productivity and respecting suppliers (Enderle \& Tavis, 1998; Schwartz \& Carroll, 2003). Hence, addressing CSR at the corporate marketing level enhances its integrity, which underpins the ethical brand concept (Powell, 2011). Thus, in this study, ethical branding:

1. is conceptualized as the sum of core values of the corporate brand (an emotional concept) (Singh et al., 2012; Urde, 2003; van de Ven, 2008);

2. is derived from three levels: organizational, product and/or its services/added value (Abratt \& Kleyn, 2012; Balmer et al., 2011; Balmer, 2013; Beverland et al., 2007; Brown \& Dacin, 1997; Brunk, 2010a; Dacin \& Brown, 2002; Urde, 2003; Urde, 2009; Urde et al., 2013; van de Ven, 2008);

3. has moral obligations (through its economic, environment and social responsibility) (Enderle \& Tavis, 1998; Balmer et al., 2011; Brunk, 2010a; Hur et al., 2014; Singh et al., 2012; van de Ven, 2008); 
4. interacts with specific stakeholders/society (Maignan et al., 2005), e.g., the industrial buyer, who is the focus of this study and in the context of the industry operates in areas like electronics, which have a greater degree of environmental responsibility through pollution, recycling, and product safety, etc.

Here, the brand is not treated simply as brand elements (e.g., logo, character, symbol, color, design or slogan) or functional values (de Chernatony, 2002) targeted at the customers, but also as brand values (that encompass functional, emotional and societal values) representing both product/services and company/corporation (Balmer et al., 2011; Brunk, 2010a; Fan, 2005; Urde, 2003; van de Ven, 2008). In other words, the term brand also refers to the company/organization (i.e., the corporate brand), and by being an ethical brand, the brand: (1) acts morally; (2) considers economic, social and environmental responsibilities; (3) has integrity, honesty, accountability and commitment to doing the right thing; and (4) creates added value for the firm, customers and its stakeholders. Adopting this behavior will be seen as doing the right thing and gaining integrity, honesty and accountability, which, in turn, could enhance a company's reputation and brand loyalty (Fan, 2005).

\section{Theoretical underpinning: Antecedents and consequences of ethical branding}

The theoretical underpinnings of the antecedents and consequences of ethical branding are developed from the perspectives of corporate marketing (Balmer et al., 2011; Beverland et al., 2007), branding (de Chernatony, 2002; Urde, 2003; van de Ven, 2008) and stakeholder perceptions (Clarkson, 1995; Maignan et al., 2005). Since ethical branding is defined as part of the corporate brand's sum of values which derive from the organization's philosophy, its members, its product or services and added value (Beverland et al., 2007; de Chernatony, 2002; Urde, 2003), these values can be categorized as functional and emotional. Functional values are represented by the product, service quality and price, while the emotional or affective values of the organization is represented by the ethical branding (Brunk, 2010; van 
de Ven, 2008). According to de Chernatony (2002), buyers take into account the corporate brand's functional consideration first, and then the emotional consideration. In other words, ethical branding is an affective outcome that results from the industrial buyer's experience of the functional values. This notion is used to underpin our conceptual model.

As long as the supplier conveys its responsibility, a customer may develop a positive evaluation (affect) and view the company as an ethical brand. The experience offered by the company may be that of providing added value through innovative, quality products and services, and being seen as a good corporate citizen, which subsequently improves its corporate reputation (Hur et al., 2014; Mulki \& Jaramillo, 2011; Schwartz \& Carroll, 2003; Singh et al., 2012). Price, considered another important functional aspect, is seen as helping to convince the buyer that the company produces a high-quality product, thereby encouraging the industrial buyer to spend more (Story \& Hess, 2010). Hence, in our study, perceived price, product and service quality (functional aspects) are considered the important antecedents of the ethical brand (an affective aspect), which, in turn, lead to favorable outcomes, such as improved reputation and brand loyalty. These relationships form a company's competitive advantage. In the next section, we discuss these variables in more detail and develop the research model and corresponding hypotheses.

Hypothesis development: The effects of product, service quality and perceived price on ethical branding, company reputation and brand loyalty

The hypothesis development for the current study has two categories: the direct effect, and the indirect or mediator effect. Initially, we discuss the direct effect before developing the mediator effect in the subsequent section. The consequences of the ethical brand are company reputation and industrial brand loyalty (Mulki \& Jaramillo, 2011; Hur et al., 2014). Examples of the functional values are product and service quality, and perceived price, which we consider to have important relationships with company reputation and brand loyalty. 
Consistently, the tangible attributes, including product, service quality and cost/price, are important antecedents of customer perceived value (Cretu \& Brodie, 2007) and the ethical brand (Parguel et al., 2011).

Because customer value is also a form of ethical branding (Singh et al., 2012; Urde, 2003), the inclusion of product and service quality is justified due to their value-added capabilities (Paluszek, 2005). The quality of a product includes its capability to perform to the customers' needs and expectations (Crosby, DeVito \& Pearson, 2003). Product quality aims to fulfill the minimum requirement specifications that are consistent with the customers' needs, such as product safety and health standards (Nnorom \& Osibanjo, 2008), and the environment (Whysall, 2000). Additionally, through an ethically oriented brand's services and products, the societal needs are met (Biraghi \& Gambetti, 2015), and the product and service qualities that conform to ethical standards differentiate themselves on the basis of an environmental or social quality (Parguel et al., 2011). To be ethical, a company must incorporate ethics into all aspects of its business practices, including the product development processes. Within highquality products, buyers may select a brand that is deemed to deliver ethical values and behave responsibly (Wartick, 2002).

With respect to service quality, companies that deliver superior service quality will be highly valued by their partners (Paluzsek, 2005). Story and Hess (2010) highlight that service quality results in good customer relationships and profitability. From a relational exchange perspective, relationship benefits include security, consistency and overall improved service quality (Payne \& Frow, 2013). For example, after-sales service is particularly important for electronic products (e.g., electronic office equipment, such as computer servers, notebooks, desktops, printers and photocopiers). If a brand provides a better quality of service than its competitors, it may be perceived that the brand is credible and reliable, which are aspects of ethical value. 
Finally, in this study, the perceived price refers to the price being charged to the buyer to cover the costs relating to enhancing the quality of the product and service. Lowengart, Mizrahi and Yosef (2003) explain that reasonable or premium pricing relates to the quality offered by the brand. This is because the quality enhancement efforts (such as training of workers, new technology and equipment, cost of recruitment of new labor, and maintenance cost of new equipment) increase the average price of production (Story \& Hess, 2010). Therefore, a brand offering a high-quality product or service may charge a higher price (Story \& Hess, 2010).

Buyers also judge the brand through its ethical responsibility (e.g., economic, social and environmental) (Balmer et al., 2011; Story \& Hess, 2010; van de Ven, 2008). For example, if manufacturers use high-quality products, they will enjoy a strong brand name (economic responsibility). In addition, as the current study focuses on electrical and electronic products, the manufacturer might also fulfill its moral responsibility concerning waste associated with the manufacturing of the products in terms of its ethical disposal (delivering its environmental responsibility). For example, a company needs the funds to develop an ethical brand, which involves training, material and labor costs, along with new process and equipment costs to support recycling or/and disposal programs to cover its stakeholders' responsibilities as a whole (Brunk, 2010a). Nnorom and Osibanjo (2008) explain that the use of electronic products produces hazards due to waste deriving from the electrical and electronic assemblies containing chemical elements. Example of the E-waste are accumulators, mercury, lead, nickel, copper, lithium, silver and so on, which affect environmental quality (Ernst \& Young LLP, 2014). Therefore, to reduce the negative effect of this waste on the environment, each company must have a comprehensive program for recycling, recovery and disposal (Nnorom \& Osibanjo, 2008) for which investment is needed. This of course affects the average cost of production, and, consequently, increases the price. 
Hence, a higher price may affect the perception of the buyer that the company offers an ethical brand in recognition of its environmental, social and economic responsibilities, and its brand loyalty (Story \& Hess, 2010). Consequently, there is a correlation between price perception and ethical branding. Therefore, the following hypotheses are tested:

H1a: Product quality will have a direct positive effect on ethical branding H1b: Service quality will have a direct positive effect on ethical branding H1c: Perceived price will have a direct positive effect on ethical branding Company reputation is defined as a particular type of feedback, received by an organization from its stakeholders, concerning the credibility of the organization's identity claims (Whetten \& Mackey, 2002:401). Company reputation is enhanced when customers feel secure about purchasing the company's products and services; thus, positive product or service performance brings many benefits to a company, while poor performance produces negative reactions (Cretu \& Brodie, 2007). Cretu and Brodie (2007) conceptualize credibility as the link between company behavior and public confidence. Thus, the better the product quality, the higher the perceived ethical branding value; consequently, when higher value is apparent (Wartick, 2002), the ethical brand is recognized as enhancing the company reputation (Fan, 2005). Additionally, in terms of social responsibility, a company that considers the laws and regulations of the country, prevents discrimination and respects social customs and cultural heritage (Brunk, 2010a; Enderle \& Tavis, 1998), may enhance its reputation as a good corporate citizen (Cretu \& Brodie, 2007). Moreover, Mazzanti and Zoboli (2006) explain that a responsible waste and recycling policy influences innovation, especially when varying manufacturing industries are involved. A company that has a recycling program may be perceived as being environmentally responsible and innovationoriented, thus enhancing its reputation (Cretu \& Brodie, 2007). Furthermore, the overall level of service offered by an organization is indicated by the customer's assessment of its service 
quality (Farrell, Souchon \& Durden, 2001). This, in turn, is related to the responsible behavior of the company to its buyers, that is, offering excellent service quality, which is itself related to ethical branding (Brunk, 2010a).

Cretu and Brodie (2007) ascertain that market responses concerning how the company image and reputation are perceived (e.g., good or bad image) are influenced not only by product, service or branding attributes, but also by price. As customers may perceive that a strong brand can enhance the trust or reduce the risk (Balmer \& Gray, 2003), especially for high-technology products - computer servers, notebook computers, electronic whiteboards, and other similar products - a higher price will enhance the credibility of the company (Ambler, Kokkinaki \& Puntoni, 2002). We thus hypothesize that product and service quality, and perceived price will have a direct effect on company reputation and formulate our hypotheses as follows:

H2a: Product quality will have a direct positive effect on company reputation H2b: Service quality will have a direct positive effect on company reputation H2c: Perceived price will have a direct positive effect on company reputation In this study, brand loyalty refers to the commitment of buyers to sustain a long-term relationship with the brand manufacturer (Lam, Shankar, Erramili \& Murthy, 2004). According to Lam et al. (2004), using a sensitivity analysis, the perception of price changes the level of influence of loyalty, sensitivity to quality, and the level of competition in a given industry. Buyers are ready to pay a higher price for a good quality product/brand with highengineering design that offers superior value compared to its competitors (Cretu \& Brodie, 2007). As a result of the high quality, these industrial buyers are willing to pay a premium price, intend or continue to use the brand and will recommend it to their business counterparts (van Riel, Mortanges \& Streukens, 2005). Therefore, maintaining product and service quality is crucial to maintaining brand equity and a relationship with industrial buyers 
(Bendixen, Bukasa \& Abratt, 2004). In addition, Jayawardhena, Souchon, Farrell and Glanville (2007) conclude that service quality has important managerial implications for customer loyalty. Thus, the higher the perception of the overall service quality, the more customers will engage with the brand as an expression of brand loyalty in the business-tobusiness context (Bendapudi \& Leone, 2002). Additionally, Story and Hess (2010), and Stanaland et al. (2011) show that industrial customers are willing to pay a premium price for brands that exhibit strong brand equity, with the buyer choosing products/services from famous brands. Thus, industrial buyers also consider higher price to be an indicator of ethical branding in their purchasing decisions (Wood, 2000). Therefore, having a strong, differentiated brand will help maintain and sustain the relationships with its customers, thereby earning buyers' loyalty in a highly competitive market (Lynch \& Chernatony, 2004). Thus, we posit that:

H3a: Product quality will have a direct positive effect on brand loyalty H3b: Service quality will have a direct positive effect on brand loyalty H3c: Perceived price will have a direct positive effect on brand loyalty

\section{The mediator effect}

Perceived price, product, service quality, company reputation and brand loyalty

Product quality is the overall excellence or superiority of a product, which can be described according to its performance, features, reliability, conformance, durability, and aesthetics (Crosby et al., 2003). Service quality refers to the ability to advise customers on technical and commercial enquiries (Beverland et al., 2007). In the electronic office equipment industry, the quality of the product and service can enhance the confidence of customers in their purchase decision-making. With enhanced confidence, risk is reduced, and the company's reputation and brand loyalty are increased (van Riel et al., 2005). The concept of ethical branding aims to create added value (Fan, 2005). In the present study, we include it as an 
affective element due to the close association between affect and added value, and to develop a more holistic ethical branding concept at the corporate level (van de Ven, 2008). In fact, one of the main contributions of the study lies within the ethical brand, which is seen as having a mediator role. As argued, one of the main research gaps is our understanding of the effect of CSR brand on marketing outcomes (such as brand equity, corporate credibility and corporate reputation) (Hur et al., 2014). However, the credibility of and the trust in the corporate brand depend on how well a company is able to use and communicate its CSR marketing strategies to its various stakeholders, which, in turn, may enhance both the corporate brand's reputation and the brand equity (Hur et al., 2014).

We posit that an ethical brand invokes strong emotions that, ultimately, lead to favorable outcomes, such as improved company reputation and increased brand loyalty. An ethically conscious brand creates superior value as an emotional component that may affect company reputation and brand loyalty (Brunk, 2012). Additionally, with the creation of value, the emotional aspect expressed in the ethical brand may also affect the responses of industrial buyers, in this case, company reputation and brand loyalty. Thus, we posit that the benefits of product and service quality, and perceived price determine the overall perceptions of the ethical brand (core value added), which influence the responses of industrial buyers, particularly their perception of the company's reputation and subsequent brand loyalty. In addition, business buyers are willing to pay a higher price for brands provided by companies with a high reputation due to the higher price of a brand being equivalent to quality (Lowengart et al., 2003). A company producing high-quality products and services has a strong brand, which enables it to charge a premium price (Lynch \& Chernatony, 2004) as customers may perceive that a strong brand enhances the trust or reduces the risk, especially for high-technology products - computer servers, notebook computers, electronic whiteboards, and other similar products - that may suffer certain set identities due to their 
association with a specific industry (as highlighted by Melewar \& Karaosmanoglu, 2006). Reputation is thus a key factor for achieving success and competitiveness (Cretu \& Brodie, 2007). Based on the above discussion, we investigate the effects of product, service quality and perceived price on brand loyalty via ethical branding (as mediator 1) and company reputation (as mediator 2), as hypothesized below:

H4a: Ethical branding mediates the effect of product quality on company reputation H4b: Ethical branding mediates the effect of service quality on company reputation H4c: Ethical branding mediates the effect of perceived price on company reputation H5a: Ethical branding mediates the effect of product quality on brand loyalty H5b: Ethical branding mediates the effect of service quality on brand loyalty H5c: Ethical branding mediates the effect of perceived price on brand loyalty Ethical branding, company reputation and brand loyalty

Olin (2004: 228) noted that the real issue facing companies today is that if the consumers do not like the way a company behaves, they are likely to go elsewhere. Many pressure groups will punish companies based on the way they behave to the public and good behavior will be rewarded with higher profits (Olin, 2014). Although being seen as ethical may not necessarily have an immediate effect (it is not guaranteed that consumers will buy the product, even after the spending activities of the company), most scholars agree that incorporating ethical marketing (Balmer et al., 2011), (or being seen to be an ethical brand - Fan, 2005) helps the long-term business performance by, e.g., enhancing the company reputation; increasing sales, profit and market shares (van de Ven, 2008); and improving the company's strategic competitive advantage (Martin \& Johnson, 2010). Fombrun, Gardberg and Barnett (2000) note that corporate reputation (built through companies that behave responsibly) may explain the buyers' decisions and commitment to a company's products. Indeed, van Rekom et al. (2014) explain that to be successful in today's environment, a company must enhance the 
level of perceived authenticity of its brand through genuine societal engagement, which improves the company reputation and ethical branding. This marks a new way for brands to potentially become sustainable (Balmer et al., 2011).

Engaging in corporate social responsibility (CSR) is no longer window dressing or lip service (Balmer et al., 2011) but a vital corporate activity because companies must behave (or be seen to behave) in a manner that benefits society and is acceptable to the public (van de Ven, 2008). Therefore, managing reputation is essential for a company to maintain long-term buyer commitment and achieve sustainability (Balmer et al., 2011). In other words, an ethical brand that acts responsibly is instrumental to business success to express a company's reputation, and the long-term success of the company depends on its integrity, and tradition of honesty and fair dealing as its ethical responsibility toward its stakeholders. Reputation is vital in the business-to-business market, and, hence, a key factor for competitive success (Cretu \& Brodie, 2007). By incorporating CSR or the ethical dimension into its strategic corporate marketing, a company can enhance buyer's loyalty and commitment (Balmer et al., 2011). Through this strategic point, brand is able to create confidence among various stakeholders regarding their relationship with the company and enhance the company's reputation. Accordingly, we propose the following hypothesis:

H6: Ethical branding mediates the effect of company reputation on brand loyalty

Based on the above discussion, we develop ethical branding and company reputation as the mediators in our model between product quality, service quality and perceived price (antecedents), and brand loyalty (consequence). We present the following model in Figure 1 to explain the above hypothesized relationships.

$<$ Insert Figure 1 Here $>$

\section{METHODOLOGY}

Research context, sampling and data collection 
This study aims to determine whether a corporate brand's functional and emotional values, that is, product, service quality and perceived price (antecedents), influence ethical branding, and, consequently, company reputation and brand loyalty (consequences) among industrial buyers of electronic office equipment in Malaysia. This context is of interest for several reasons. First, CSR activity is increasing and has gained national interest. Malaysia established businesses or companies (from the private sector - small to large multinational corporations) to assist and speed up the Government Transformation Programs (GTP) as part of the New Economic Model (NEM) at the beginning of 2010 to achieve a sustainable society (National Economic Advisory Council, 2010). It is the government's aspiration to create a united country with strong moral values and a caring and economically just society (UNICEF Malaysia, 2009). Therefore, because the acceptance of CSR is an emerging notion within the region, this research is timely, especially to guide practitioners, businesses and companies that wish to operate within this market. Second, most of the empirical research has been conducted in the Western context (van de Ven, 2008), and our understanding of the empirical relationship between CSR and corporate branding in the Asian market remains limited (ChiShiun et al., 2010; Nguyen, Melewar, \& Schultz, 2016). However, as the relative importance that is attached to corporate branding differs as much between countries as it does between institutions corporate brand it must be considered geographically (Balmer \& Liao, 2007). For example, emerging markets, such as the Asian market, are considerably different from the Western context. Furthermore, emerging markets offer tremendous growth opportunities for firms from developed countries, such as the USA, and it is therefore important to determine the corporate branding strategy that is preferred or acceptable to these markets (Xie \& Bogg, 2006). Third, the product and identity of the industry type selected in our study - electronic equipment - is considered relevant and of concern to groups or stakeholders such as environmentalists (Melewar \& Karaosmanoglu, 2006). Finally, empirical research offering a 
definition from the ethical brand perspective at the company or corporate level in the business-to-business context remains an under-researched area (Chi-Shiun et al., 2010).

In particular, we focus on the ethical brand construct and its effects in the context of electronic office equipment purchases. Our study population consists of companies that use electronic office equipment in Peninsular Malaysia. We conducted both a mail and online survey. We obtained the companies' data, including their mailing and e-mail addresses, from the Companies Commission of Malaysia (CCM) and the Malaysian Industrial Development Authority, 2008 - MIDA). The sampling frame is industrial buyers with the respondents consisting of CEOs, general managers or appointed representatives (at the managerial level) with sufficient experience in buying decisions, such as those who are directly responsible for buying electronic office equipment for their companies. Another criterion of the selection is that their companies must be legally registered with the $\mathrm{CCM}{ }^{2}$

Prior to the distribution of the questionnaires, the respondents were screened and selected and those who did not match any one of the above criteria were omitted. The study's approach is compatible with that used by Cretu and Brodie (2007) and van Riel et al. (2005). In total, we distributed 1,356 questionnaires through the Internet and mail across twelve districts in Peninsular Malaysia. There were 291 returns (21.4\% response rate). Specifically, of the 291 questionnaires returned, 186 were completed via mail, and the remaining 105 questionnaires were completed online. The final total usable sample was 272, as 19 were removed due to inadequate responses. We thus achieved a response rate of $20 \%$, which is comparable to the response rates of previous studies. For example, van Riel et al. (2005) achieved a response rate of $8.8 \%$ and Wilde, Kelly and Scott (2004), 18.2\%. Among the respondents, the majority was male (63.2\%), aged between 30 and $44(86.8 \%)$, with an average working experience of 11 to 15 years, $(63.2 \%)$ and having at least an undergraduate/bachelor level of education (67.3\%). These respondents included CEOs 
(4.4\%), general managers $(25.7 \%)$, production managers $(15.4 \%)$, financial managers

(35.7\%), and marketing managers (18.0\%). On average, their income level was RM

7,000.00-7,999.00 per month. ${ }^{3}$

\section{Measures and instrument development}

To generate measures for all six constructs developed, the existing literature served as our starting point. Items were evaluated for the closest match and suitability for our study's objectives with minimum adjustment to our context; namely, business buyers and electronic office equipment. In total, 44 items were developed, as shown in Table 1. The first construct, product quality, measured through 7 items, was adapted from van Riel et al. (2005) and Crosby et al. (2003). It captured the overall excellence or superior quality of the product, innovation (van Riel et al., 2005) and durability (Crosby et al., 2003). For service quality, 8 items were adapted from Jayawardhena et al. (2007) and van Riel et al. (2005). Examples included items that expressed "information service" and "excellent personnel service". For perceived price, this study utilized 5-item scales to capture several aspects considered important in the branding and business buyer context, such as comparative and competitor pricing (Kukar-Kinney \& Grewal, 2006), clear and good price information (Bolton, Kannan \& Bramlett, 2000), and high pricing indicates product quality (Lowengart, Mizrahi \& Yosef, 2003; Kukar-Kinney \& Grewal, 2006).

We operationalized the ethical branding construct in accordance with the corporate marketing approach, which defines it as a moral obligation delivered through economic, social and environmental responsibilities (Enderle \& Tavis, 1998; Fan, 2005; Schwartz \& Carroll, 2003; van de Ven, 2008). In total, the ethical branding concept was represented by 12 items, capturing three different dimensions; namely, economic, social responsibility and environmental responsibility. The economic responsibility captured "maximize profit," "increase of wealth," and "respect to suppliers/customers" (Enderle \& Tavis, 1998). For the 
attributes of social responsibility, we measured the responsibility toward the political and socio-cultural system of society (Enderle \& Tavis, 1998), and the items for the final attribute, environmental responsibility, refer to the company policy regarding natural resources, such as raw materials and energy, or its recycling and disposal program to avoid overwhelming the environment through its waste and pollution outputs. We utilized items concerning environment responsibility from both Enderle and Tavis (1998), and Nnorom and Osibanjo (2008).

Company reputation refers to certain feedback received by an organization from its stakeholders concerning the credibility of the organization's identity claims (Whetten \& Mackey, 2002) and the association that the buyer has with the company (Brown \& Dacin, 1997). The items were derived from Cretu and Brodie (2007). Finally, brand loyalty was represented by 8 items from Morgan and Hunt (1994), van Riel et al. (2005) and Davis (2003), and refers to loyalty and commitment in the business-to-business context (Morgan \& Hunt, 1994; Singh \& Sirdeshmukh, 2000). All measures used a seven-point Likert scale (from $1=$ strongly disagree to $7=$ strongly agree). Table 1 shows more details for each construct, the appropriate dimensions, and the respective sources. Furthermore, in the study's questionnaire, we asked the respondents to select one brand from a given list of common brands of electronic office equipment (such as Canon, Hewlett Packet, etc.) or if the brand was not listed, the respondent was given an option to indicate the brand they currently used/owned in their office. This is referred to as "Brand X" in the questionnaire. Once a brand was selected, respondents were then directed to fill in the remaining statements in the questionnaire, indicating their agreement/disagreement based on their earlier chosen brand (Brand X).

$$
<\text { Insert Table } 1 \text { Here }>
$$

\section{Pre-test and pilot study}


For content validation purposes (before the main data collection was carried out), we conducted a pre-test to examine the adopted items and study measures, which was followed by a pilot study. We involved five experts and practitioners as the participants in the pretesting process to improve the content and face validity, and, upon their satisfaction with the content and readability of the measures, we proceeded to test the internal consistency of the measures by conducting a pilot test. This pilot test was conducted with industrial buyers of electronic office equipment using an e-mail survey sent to the three main locations of electronic office equipment factories and service offices (Kuala Lumpur, Selangor \& Negeri Sembilan). Out of 300 questionnaires administered to a convenience sample of industrial buyers, we received 50 useable questionnaires. The results of the pilot study indicated that the six constructs have a high level of internal consistency (Cronbach's Alpha >0.7): product quality (0.86), service quality (0.87), perceived price (0.78), ethical branding $(0.88)$, company reputation (0.74) and brand loyalty $(0.85)$. These results appear to be consistent with previous studies, including van Riel et al. (2005), and Cretu and Brodie (2007). The study then proceeded with the actual main data collection to which 272 industrial buyers responded.

\section{RESULTS}

\section{Step 1: Confirmatory factor analysis - CFA}

To analyze the data from the main study (272 responses), the structural equation modelling (SEM) approach was implemented via the latest version of AMOS 20 and the default method - Maximum Likelihood (ML). In particular, a two-step approach to test the measurement model's validity and reliability (in step one - CFA), and nomological validity (in step two structural full model), as proposed by Anderson and Gerbing (1988), was carried out on all of the study's constructs (product quality, service quality, perceived price, ethical branding, company reputation, and brand loyalty). 
Thus, all 44 items were subjected to CFA, the measurement model, where a purification process was conducted to establish the construct validity and reliability of all the items generated. The initial results of the CFA measurement analysis (in step one) showed a poor fit and had to be re-specified (Hair, Anderson, Tatham \& Black, 2008). The results of $\left(\chi^{2}\right)$ ${ }_{(272)}=2112.89 ; \mathrm{p}<.01 ; \chi^{2} / \mathrm{df}=2 ; \mathrm{GFI}=0.76 ; \mathrm{TLI}=0.85 ; \mathrm{CFI}=0.86 ;$ and $\mathrm{RMSEA}=0.06$ described a marginal fit. Several items that were cross-loaded with high modification indexes (MI) and large standardized residuals (SR) (>2.58) were dropped from further analysis (Byrne, 2001; Long, 1983). A total of 11 items were dropped: one from Product Quality, two from both Service Quality and Perceived Price. Additionally, two further items from ethical branding, two from Company Reputation and two from brand loyalty were also dropped due to large standardized residuals (Byrne, 2001). Table 1 indicates in detail the items that were removed during the purification process. The final measurement model resulted in 33 items, representing all six constructs under study with an acceptable fit $\left(\chi^{2}(272)=524.06, p<.01\right.$; $\chi^{2} / \mathrm{df}=1.68 ; \mathrm{GFI}=0.87$ (marginal fit); TLI $\left.=0.92 ; \mathrm{CFI}=0.93 ; \mathrm{RMSEA}=0.05\right)$ (Hair et al. 2008).

Convergent validity was also supported in this study, with all parameter estimates $>0.5$, (Kline, 1998) and all items statistically significant at $\mathrm{p}<.01$ (Anderson \& Gerbing, 1988) (see Table 1 for the standardized loadings for each item). Construct reliability tests were performed using both Composite and Cronbach's alpha, and all were above the recommended level, as shown in Table 2. The correlation (the covariance) among the constructs was also acceptably low, ranging from $0.47-0.69$, (Byrne, 2001); AVE $=>0.5$ (Fornell \& Larcker, 1981) and the square root of each construct's AVE was greater than the bivariate correlation coefficients, which ranged from $0.41-0.61, \mathrm{p}<.01$, (see Table 2 ). There were no substantial cross-loadings between the measured and error terms, with standardized residuals all $<2.58$ (Garver \& Mentzer, 1999). Thus, the assessment results support the adequacy of the 
discriminant validity of the measurement model. Next, the study proceeded to step two (full structural model) to test the hypothesized model (H1a to H6). The final result of the full structural model showed a good fit (for example, $\chi^{2}(272)=882.27, \mathrm{p}<.01 ; \chi^{2} / \mathrm{df}=1.83 ; \mathrm{GFI}$ $=0.86$ (marginal fit); TLI $=0.91 ; \mathrm{CFI}=0.92 ; \mathrm{RMSEA}=0.05)$ (Hair et al., 2008).

\section{Step 2 The full structural model - hypotheses tests}

We tested all the direct effects via AMOS, and the results exhibited significant positive effects $(\mathrm{H} 1 \mathrm{a}-\mathrm{H} 3 \mathrm{c})$ with the exception of two hypotheses; namely, H2b and H3c (the effect of service quality $\rightarrow$ company reputation and perceived price $\rightarrow$ brand loyalty, respectively); thus the study rejected these hypotheses. The study also found that all three direct effects as hypothesized (product, service and perceived price) significantly influenced ethical branding $(\beta=0.24, p<.01 ; \beta=0.43, p<.01$ and $\beta=0.15, p<.05$, respectively). Hence, H1a, H1b and H1c were supported. This result also indicated that these three predictors (product, service and perceived price) significantly explained $42 \%$ of the variance (or squared multiple correlations $-\mathrm{SMC})$ in the ethical branding, with service quality $(0.47$ in structural coefficient) having the greatest effect. The remaining direct effects $((\mathrm{H} 2 \mathrm{a}, \mathrm{H} 2 \mathrm{c})$ and $(\mathrm{H} 3 \mathrm{a}$, H3b) also positively affected company reputation and brand loyalty, respectively. See Table 3 for the detailed results of the hypotheses for all the direct effects.

\section{Mediation test results}

To establish the mediation effects, as conceptualized earlier (i.e., H4a, H4b, H4c, H5a, H5b, H5c and H6), our study used the method known as PROCESS macro, Version 2.16 (Hayes, 2013; Hayes \& Preacher, 2004; 2008). The PROCESS method allows researchers to determine a more confident and robust interpretation of whether the mediator variable is significant and important to the theoretical proposition (Hayes, 2012; Preacher \& Hayes, 2004), particularly when using a small sample size (Shrout \& Bolger, 2002). Specifically, we 
established mediation using guidelines proposed by Preacher and Hayes (2008), Preacher and Kelley (2011), and Zhao et al. (2010); as set out below:

(1) If the introduction of a mediator variable (M) into the $\mathrm{X} \rightarrow \mathrm{Y}$ relationship (known as the c' path) reduces the effect sizes $(\beta)$ of the original direct effect, it indicates mediation;

(2) Confidence Interval $(\mathrm{CI}) \neq 0$ indicates that mediation has occurred (Preacher $\&$ Hayes, 2008);

(3) An $X \rightarrow Y$ direct effect, where an insignificant result ( $p>.05)$, particularly after $M$ is introduced (c' path), indicates full mediation, while a significant result demonstrates a partial case (Baron \& Kenny, 1986; Preacher \& Kelley, 2011; Zhao, Lynch, \& Chen, 2010);

(4) In the event of partial case, further examination is proposed using "effect sizes", as they could strengthen the justification for full or partial mediation (Preacher \& Kelley, 2011). In particular, two effect sizes were chosen for the current study; namely, the Completely Standardized Indirect Effect $\left(\mathrm{ab}_{\mathrm{cs}}\right)$ and Percent Mediation $\left(\mathrm{P}_{\mathrm{M}}\right)$ based on the guidelines proposed by Preacher \& Kelley (2011). The effect sizes must fulfil all three general criteria (1) interpretable scaling, (2) confidence interval available, and (3) independent of sample size), such as in the case of ( $\left.a b_{c s}\right)$. Finally, $P_{M}$ is also the most widely used measure of effect size in previous research (Preacher \& Kelley, 2011).

As shown in Table 4, the results of our analyses indicate support for stronger or full mediation on two hypotheses; namely, service quality $\rightarrow$ ethical branding $\rightarrow$ company reputation (H4b), and perceived price $\rightarrow$ ethical branding $\rightarrow$ brand loyalty (H5c). This is because the introduction of a mediator variable (ethical branding or c' path) reduces both $(\beta)$ of the original direct effects; as shown in Table 4 . Both $\mathrm{CI} \neq 0$ and at least one of the 
hypotheses (H4b in this case) indicate an insignificant direct path (c' path), particularly after ethical branding is introduced in the service quality $\rightarrow$ brand loyalty relationship (Preacher $\&$ Hayes, 2008; Zhao et al., 2010). Specifically, service quality $\rightarrow$ ethical branding $\rightarrow$ company reputation (H4b) produced: $a$ path $-\beta=0.57, \mathrm{p}<.01$ and $b$ path $-\beta=0.50, \mathrm{p}<.01$, while the direct path of service quality $\rightarrow$ company reputation after the [M, c' path] was controlled was found to be insignificant. Hence, this result indicates a case for full mediation. That is, $\beta=$ $0.11, \mathrm{p}=0.08,95 \% \mathrm{CI}[\mathrm{LL}-0.20, \mathrm{UL}-0.39]$, where $95 \%$ denotes the confidence interval (CI) at both the Lower Limit (LL) and the Upper Limit (UL). As for H5c or perceived price $\rightarrow$ ethical branding $\rightarrow$ brand loyalty, a similar result favoring a stronger mediation case was found. Although the result as shown in Table 4 indicates both paths (direct and indirect) were significant for $\mathrm{H} 5 \mathrm{c}$ (a partial mediation case), both effect sizes, $\left(\mathrm{P}_{\mathrm{M}}\right)$ and $\left(\mathrm{ab} \mathrm{b}_{\mathrm{cs}}\right)$, indicate that the mediator accounted for more than half of the total effect (c path) $\left(\mathrm{P}_{\mathrm{M}}=0.61\right.$ or $\left.61 \%\right)$ and $a b_{c s}=0.30,(\beta=0.23, p<.01,95 \%$ CI $[0.17,0.31]) ;$ thus supporting a stronger mediation via ethical branding (Preacher \& Kelley, 2011). As explained by Preacher and Hayes (2008), and Preacher and Kelley (2011), when both paths direct and indirect are significant, a further examination through additional techniques could further strengthen the justification for full or partial mediation (Preacher \& Kelley, 2011). Similarly, H4b's mediation effect accounts for almost three quarters of the total effect (c path) $\left(\mathrm{P}_{\mathrm{M}}=73 \%\right)$ and $\mathrm{ab}_{\mathrm{cs}}=0.28,(\beta=.30, \mathrm{p}<.01$, $95 \% \mathrm{CI}[0.22,0.40])$. The $a b_{\mathrm{cs}}=0.28$ indicates that $\mathrm{Y}$ (company reputation) decreases by 0.28 standard deviations for every 1 in X (service quality) indirectly via ethical branding (Preacher \& Kelley, 2011). Contrasting results were also observed across all the mediation hypotheses through the $\mathrm{P}_{\mathrm{M}}$ column (Table 4), favoring the stronger mediation impact, thus supporting the two hypotheses (H4b and H5c) for full mediation. Finally, as depicted in Table 4, the remaining hypotheses (H4a, H4c, H5a, H5b and H6) indicate partial mediation since both paths (direct and indirect) were significant and the mediator accounted for less than half of 
the total effect (c path) ( $\mathrm{P}_{\mathrm{M}}$ ranged between 0.40 and 0.49$)$; thus, supporting partial mediation. Table 4 shows the detailed results of Preacher and Kelley's (2008) PROCESS method with further examination of the mediator role through the Percent Mediation $\left(\mathrm{P}_{\mathrm{M}}\right)$ and Completely Standardized Indirect Effect (abss) (Preacher and Kelley (2011).

$<$ Insert Table 3 \& 4 Here $>$

\section{DISCUSSION}

\section{Theoretical Implications}

This study contributes to the literature in the following ways. First, we offer insights into how CSR dimensions can be conceptualized and operationalized from a corporate marketing and branding perspective. Second, we develop an integrated consumer response model and offer empirical evidence of the impact of ethical branding on other corporate brand equity variables and marketing outcomes, including corporate reputation brand loyalty. In particular, the study examined the role of ethical branding (EB) as a mediator. Finally, as the study focuses on corporate branding, we propose a different stakeholder approach focusing on the industrial buyer rather than on individual buyers, unlike past research. The following section discusses these theoretical contributions in more detail.

First, while the previous research differentiates and emphasizes a firm's corporate brand identity to its multiple stakeholders through functional values (e.g., product/service quality, prices) and/or emotional values (corporate credibility or corporate personality traits) separately, this study proposes a new way for a corporate brand to project and differentiate itself via CSR elements through its products, services and perceived price. In particular, we define the ethical brand at a more abstract/corporate level through a firm's moral responsibility to its multiple stakeholders, delivered through economic, social and environmental factors. That is, an organization can express these moral obligations through values derived from functional/tangible attributes (expressed through an ethical orientation of 
its products or services), for example, a firm's product program related to recycling, disposal strategy, social quality (Brunk, 2010a), or its economic attributes, maximizing the industrial buyer's profit by producing an ethically oriented product (Powell, 2011). Because previous research investigated the ethical brand individually, only a partial effect of the corporate brand and marketing outcomes was understood in relation to consumer response (Loe et al., 2000). However, it is more effective to combine these values as they not only form or sum up the core values of the corporate brand (Urde, 2003), but also establish a more abstract association at the corporate level; hence, the organization could leverage them across individual products within the portfolio (Beverland et al., 2007). Ethical branding is thus an important intangible firm asset that should be embedded in the overall corporate marketing strategy (Olin, 2014).

Second, although there is already a stream of research proposing differentiation through ethical dimensions (Balmer et al., 2011; Stanaland et al., 2011; Singh et al., 2012), its focus is primarily on the product basis (Brunk, 2012), and its antecedents and consequences among consumers are still unclear due to the lack of empirical findings (Brunk, 2010b; Hur et al., 2014). The current study offers a conceptual understanding in an integrated manner, whereby EB is proposed to be a mediator variable in relation to its antecedents (product, service quality and perceived price) and its consequences (corporate reputation and brand loyalty). In particular, this study's originality lies in the exploration of the mediator role of an ethical brand and its relationships (antecedents and consequences). We develop and empirically test the relationships between the ethical brand concept, its antecedent effects (including product, service quality and perceived price) and its outcome effects, which include buyers' reactions toward the company reputation and loyalty toward the brand. Our study is important for academics and practitioners, who may appreciate the ethical aspects of branding that are more significant in the buyers' evaluations in the business-to-business context. Likewise, 
through the mediation analyses, the effect of ethical branding perceptions on corporate brand is explained (Hur et al., 2014; Singh et al., 2012). The study shows that corporate credibility (based on consumer trust) enhances corporate reputation when ethical branding is a mediator. In addition, the study found that certain predictors are more important than others in customers' evaluations of the ethical brand. Past research has illustrated that product quality, service quality (Cretu \& Brodie, 2007) and perceived price are important factors influencing customer value as an expression of the ethical aspect (Sagar, Singh \& Agrawal, 2006; Story \& Hess, 2010). In particular, products differentiated on the basis of environmental and social qualities are seen as ethical (Balmer et al., 2011; van de Ven, 2008). Between service quality and company reputation, however, the result indicates the opposite (not significant). The insignificant result here can be explained in two ways. First, since the study context is industrial buyers of electronic office equipment, the product quality is emphasized rather than the services aspect. Industrial buyers are concerned about the quality of the electronic product with regard not only to its functional aspects but also to how it adds value, such as recycling or disposal policy (Brunk, 2010a). Second, in the Malaysian context, suppliers must ensure that the quality of the products meet the ethical requirement of being seen as green (e.g., to the environment), as this is a consideration criterion set not only by most of their industrial buyers before making their purchase decision but also by producing or going 'green', which allows them to win awards and gain accreditation, thus resulting in a better reputation.

Likewise, Sagar et al. (2006) explain that one of the important elements of brand positioning in Asia (Indian context) is to emphasize the ethical attributes (which includes product social acceptability, consumer value, ethical issue in pricing, culture and the geographic relevancy of the product). Ultimately, this forms the brand identity of the company. Because previous research focuses more on the Western context, such as the USA, the empirical findings from other continents are limited (van de Ven, 2008). 
Nevertheless, service quality has a positive and significant indirect effect on company reputation via the ethical brand. This suggests that service quality can still enhance the company reputation if the company provides an ethical brand, or the brand does not result in any negative effect for its stakeholders as a whole. In other words, a positive response or reaction to company reputation is achieved when the brand is considered ethical through the quality of service offered by the company. This constitutes the ethical foundation in marketing (Balmer et al., 2011; Olin, 2014; van de Ven, 2008) to aid the organization to successfully communicate what it intends to society while maintaining genuine societal engagement (van Rekom et al., 2014). The ethical brand represents the value of trust by offering superior value with high integrity and concern for stakeholders. We thus confirm the theoretical frameworks constructed from the previous literature, in which product quality and service quality are considered important aspects of a brand and seen as ethical by industrial buyers (Cretu \& Brodie, 2007; Fan, 2005; Paluszek, 2005).

Our final contribution is the stakeholder approach. Because previous research has focused on the functional and emotional values on a more individual basis, the intangible attributes the effect (EB) on marketing outcomes - are not realized among other stakeholders, such as industrial buyers or suppliers (Brunk, 2010a; Chi-Shiun et al., 2010; Hur et al., 2014). By providing the empirical findings regarding a different stakeholder group (industrial buyers in electronic office equipment), this study adds to the current literature concerning how this group of customers behaves in their purchase decision-making. While, at the individual level, the ethical brand (emotional values) is concerned with the issues related to fair pricing, public responsibility, leadership and brand success (Page \& Fearn, 2005), at the industrial buyer level, stakeholders are willing to pay a higher price due to the ethical orientation of a brand (product or services) (Balmer et al., 2011; van de Ven, 2008). Further, industrial buyers are also keen to associate themselves with ethically oriented brands and suppliers because this 
will add credibility to their reputation among their own stakeholders (Mulki \& Jaramillo, 2011). Hence, responsibility is a key concept, formulated by a moral statement that can manage risk and uncertainty (Stahl, 2005).

In a similar vein, we found an interesting result with regard to perceived price and the mediator variables: ethical branding and company reputation. That is, perceived price is found to fully mediate ethical branding and partially mediate company reputation to explain industrial buyers' brand loyalty. Industrial buyers are willing to pay more because they perceive that companies that are selling electronic office equipment fulfill their economic, environmental and social responsibilities. Earlier, we argued that with certain types of industry, companies must behave responsibly toward the environment; however, this act incurs greater costs and increased prices are therefore regarded as acceptable (Story \& Hess, 2010). Therefore, the industrial buyers in this context are somewhat ethically conscious. Zabid and Alsagoff (1993) found that Malaysian managers have high perceived ethical values in several sectors, including industrial manufacturing. Industrial buyers are willing to pay the higher price but only if the activity of the company considers the responsibility to its stakeholders as an expression of the ethical brand. Consequently, organizations will prosper by delivering products and services that benefit society (Maas \& Liket, 2011). Story and Hess (2010) explain that when customers are committed (through an ethical brand), they become insensitive to price asymmetries, paying more without regard to the objective quality differences.

In summary, the current research's originality lies within the conceptual and operational aspects of the ethical brand from a corporate marketing and branding perspective; providing an empirical understanding of how the concept works (mediator role) and its relationships (antecedents and consequences) in the context of industrial buyers in an emerging market in Southeast Asia, namely, Malaysia. Therefore, product quality, service quality and perceived 
price are all important criteria for a brand to be perceived as ethical (Brunk, 2012). We demonstrate that a good brand contains an ethical standard and that brand value must be assessed by both financial and ethical measures. Thus, brands must satisfy stakeholders as a whole.

\section{Managerial Implications}

This study has several managerial implications. Because ethical consumerism is evidently rising (Parguel et al., 2011), managers could spend their marketing budget on activities that will portray them as being ethical, especially when addressing multiple stakeholders. Management decisions should be based not only on a single type of customer or shareholder but also on stakeholders, such as the business buyers or suppliers (Chi-Shiun et al., 2010; Palazzo \& Basu, 2007; Stanaland et al., 2011).

Overemphasis on ethical activities in an organization's marketing communication might be misconstrued by the stakeholders, however, and the stakeholders' perception of the sincerity of the company will be diminished (van de Ven, 2008). From the current study's findings, buyers are willing to pay a higher price in this industry and trust their brands due to their overall perception and evaluation: that the company has done the right thing and behaves responsibly (an ethical brand). Therefore, communicating and engaging with society is vital and should begin in the early stages of corporate strategy planning. With consistent implementation, the brand will develop an authentic communication element and increase the level of its sincerity (van Rekom et al., 2014). Such sincerity could then enhance the company's image and reputation among the stakeholders (Bowen, 2004), and, potentially, may resolve any problems, particularly when companies must address innumerable stakeholders across different countries. Managers must therefore consider the ethical brand cost when producing the products as well as in communicating it to constituents. Likewise, suppliers must consider that the financial burden that accompanies compliance with the 
market situation is inevitable; however, ultimately, such compliance will ensure committed customers, long-term profitability and the management of the supplier-buyer relationship (Story \& Hess, 2010).

Although, at present, there is no common corporate view of how to resolve the lack of guarantee that consumers will buy a product, even if a company spends time and money on ethical activities (Olin, 2004), both the public and pressure groups are watching these companies, and will reward them positively if they behave in an acceptable manner (Olin, 2014). Nevertheless, most scholars agree that incorporating ethical marketing (Balmer et al., 2011) or being seen as an ethical brand (Fan, 2005) helps long-term business performance, e.g., by enhancing company reputation; increasing sales, profit and market share (Maas \& Liket, 2011; van Rekom et al., 2014); and, hopefully, improving the company's strategic competitive advantage.

Based on the findings of this study, we conclude that ethical business practices, i.e., ethical branding, may be applied by companies to gain a competitive advantage. Gaining increased brand loyalty through an ethical brand is essential for business survival and growth. Encouraging ethical decision-making is essential in socially responsible branding programs if a firm is to achieve a good image and facilitate self-reinforcing, positive outcomes (Caza and Cameron, 2004) that can help to protect them from their competition.

\section{LIMITATIONS AND FUTURE RESEARCH}

Ethical branding is an under-researched concept. Thus, the current definition is based on limited conceptual studies, such as those conducted by de Chernatony (2002), Urde (2003), Fan (2005), van de Ven (2008); Balmer et al. (2011), Powell (2011) and Maignan et al. (2005), who consider the moral, economic, social and environmental dimensions of ethical branding (Swhartz \& Carroll, 2003). However, in recognition that there may be other dimensions (such as sales/financial impact), further work is required to validate the current 
concept and other dimensions to increase the generalizability and applicability of the framework. More empirical evidence is needed to validate the sub-concepts and measures in other study contexts. Although the current study has shed light on the importance of practicing ethics in business and being seen to be ethical (or an ethical brand), more research is needed to further develop the ethical brand concept to enhance a company's reputation as well as by creating loyalty among the company's buyers. It is also noted that the current empirical findings should be interpreted within the context under study. Finally, future research could investigate these antecedents and the EB dimensions separately to address the corporate brand positioning more clearly in different contexts/settings and across different stakeholders.

\footnotetext{
${ }^{1}$ We note that this is just one way to define an ethical brand. As highlighted by both Okoye (2009) and Votaw (1972), CSR can mean many different things (not necessarily limited to only economic, social and environment responsibility), but the general understanding is that it is about 'being responsible for' or 'a social responsible behavior in the ethical sense' (Votaw, 1972, p. 25). In line with this view, the current paper uses this approach to determine how we perceive the ethical brand of a firm.
}

${ }^{2}$ More details on the population of companies are available on request from the authors.

${ }^{3} 1$ Malaysian Ringgit $=0.23$ USD. 


\section{REFERENCES}

Abratt, R., \& Kleyn, N. 2012. Corporate identity, corporate branding and corporate reputations: Reconciliation and integration. European Journal of Marketing, 46:10481063.

Anderson, J.C. \& Gerbing, D.W. 1988. Structural Equation Modelling in practice: a review and recommended two-step approach. Psychological Bulletin, 103: 411-423.

Andriof, J., \& McIntosh, M.2001. Perspectives on corporate citizenship. Sheffield: Greenleaf Publishing.

Balmer, J.M.T. \& Gray, E.R. 2003. Corporate brands: what are they? What of them?" European Journal of Marketing, 37: 972-997.

Balmer, J. M., \& Greyser, S. A. 2006. Corporate marketing: Integrating corporate identity, corporate branding, corporate communications, corporate image and corporate reputation. European Journal of Marketing, 40: 730-741.

Balmer, J. M. 2011. Corporate marketing myopia and the inexorable rise of a corporate marketing logic: Perspectives from identity-based views of the firm. European Journal of Marketing, 45: 1329-1352.

Balmer, J. M., Powell, S. M., \& Greyser, S. A. 2011. Explicating ethical corporate marketing. Insights from the BP Deepwater Horizon catastrophe: The ethical brand that exploded and then imploded. Journal of Business Ethics, 102:1-14.

Balmer, J. M. 2013. Corporate brand orientation: What is it? What of it. Journal of Brand Management, 20: 723-741.

Biraghi, S. \& Gambetti, R.C. 2015. Corporate branding: Where are we? A systematic communication-based inquiry. Journal of Marketing Communications, 21:260-283.

Baron, R.M. \& Kenny, D.A. 1986. The moderator-mediator variable distinction in social psychological research: Conceptual, strategic, and statistical considerations. Journal of Personality and Social Psychology, 51: 1173-1182.

Brown, T. J. 1998. Corporate associations in marketing: Antecedents and consequences. Corporate Reputation Review, 1:3: 215-233.

Brown, T. J., \& Dacin, P. A. 1997. The company and the product: Corporate associations and consumer product responses. Journal of Marketing, 1: 68-84.

Byrne, M. B. 2001. Structural Equation Modelling with AMOS: Basic Concepts, Applications and Programming. New Jersey: Lawrence Erlbaum Associates.

Chi-Shiun, L., Chih-Jen, C., Chin-Fang, Y. \& Da-Chang, P. (2010). The effects of corporate social responsibility on brand performance: The mediating effect of industrial brand equity and corporate reputation. Journal of Business Ethics, 95: 457-469. 
Bendixen, M., Bukasa, K.A. \& Abratt, R. 2004. Brand equity in the business-to-business market. Industrial Market Management, 33: 371-80.

Beverland, M., Napoli, J. \& Yakimova, R. 2007. Branding the business marketing offer: Exploring brand attributes in business markets. Journal of Business and Industrial Marketing, 22: 394-399.

Bhattacharya, CB. \& Sen, S. 2004. Doing better at doing good: When, why, and how consumers respond to corporate social initiatives. California Management Review, 47: 924.

Bolton, R. N., Kannan, P. K., \& Bramlett, M. D. 2000. Implications of loyalty program membership and service experiences for customer retention and value. Journal of the Academy of Marketing Science, 28: 95-108.

Bowen, S. A. 2004. Organizational factors encouraging ethical decision-making: An exploration into the case of an exemplar. Journal of Business Ethics, 52: 311-324.

Brunk, K. H. 2010a. Exploring origins of ethical company/brand perceptions-A consumer perspective of corporate ethics. Journal of Business Research, 63: 255-262.

Brunk, K. H. 2010b. Exploring origins of ethical company/brand perceptions: Reply to Shea and Cohn's commentaries. Journal of Business Research, 63:1364-1367.

Brunk, K. H. 2012. Un/ethical company and brand perceptions: Conceptualizing and operationalizing consumer meanings. Journal of Business Ethics, 111: 551-565.

Carroll, A. B. 2000. Ethical challenges for business in the new millennium: Corporate social responsibility and models of management morality. Business Ethics Quarterly, 10: 3342.

Carroll, A., \& Buchholtz, A. (2014). Business and society: Ethics, sustainability, and stakeholder management. USA: Cengage Learning.

Caza, A.B. \& Cameron, K.S. 2004. Ethics and ethos: the buffering and amplifying effects of ethical behavior and virtuousness. Journal of Business Ethics, 52: 169-178.

Clarkson, M. E. 1995. A stakeholder framework for analyzing and evaluating corporate social performance. Academy of Management Review, 20: 92-117.

Companies Commission of Malaysia (CCM) 2007. Available at: www.ssm.com.my; date accessed: 29 March 2014.

Cretu, A.E. \& Brodie, R.J. 2007. The influence of brand image and company reputation where manufacturers market to small firms: A customer value perspective. Industrial Marketing Management, 36: 230 - 240.

Crosby. B.L., DeVito. R. \& Pearson, M.J. 2003. Manage your customers' perception of quality. Review of Business, 24:18-24. 
Dacin, P. A., \& Brown, T. J. 2002. Corporate identity and corporate associations: A framework for future research. Corporate Reputation Review, 5: 254-263.

Davies, G., Chun, R., da Silva, R. V., \& Roper, S. 2004. A corporate character scale to assess employee and customer views of organization reputation. Corporate Reputation Review, 7: $125-146$.

Davis, D.F. 2003. The effect of brand equity in supply chain relationship.

The University of Tennessee: Knoxville, Available at: http://trace.tennessee.edu/cgi/viewcontent.cgi?article $=3428 \&$ context $=$ utk graddiss; date accessed: 20 January 2014

Ernst \& Young LLP (2014) Digi Sustainability Report 2014. Available at:

http://www.digi.com.my/sustainability/pdf/DigiSR2014.pdf; date accessed 25 April 2016

Enderle, G. \& Tavis, L.A. 1998. A balanced concept of the firm and the measurement of its long-term planning and performance. Journal of Business Ethics, 17: 1129-1144.

Fan, Y. 2005. Ethical branding and corporate reputation. Corporate communications, An International Journal, 10: 341-350.

Fombrun, C.J., Gardberg, N.A., \& Barnett, M.L. 2000. Opportunity platforms and safety nets: corporate citizenship and reputational risk. Business and Society Review, 105: 85106.

Farrell, A.M., Souchon, A.L. \& Durden, G.R. 2001. Service Encounter Conceptualisation: Employees' Service Behaviours and Customers, Service Quality Perceptions. Journal of Marketing Management, 17: 577-93.

Fornell, C., \& Larcker, D. F. 1981. Evaluating structural equation models with unobservable variables and measurement error. Journal of Marketing Research, 18: $39-50$.

Garver, M.S. \& Mentzer, J.T. 1999. Logistics research methods: employing structural equation modelling to test for construct validity. Journal of Business Logistics, 20: 3353.

Hair, J. F., Anderson, R., E., Tatham, R.L. \& Black, W.C. 2008. Multivariate Data Analysis. 7th Edition. USA: Prentice Hall, Pearson Educational International.

Hayes, A. F. 2013. Introduction to Mediation, Moderation, and Conditional Process Analysis: A Regression-Based Approach. New York: Guilford Press. Available at: http://processmacro.org/index.html; date accessed: 25 January 2017.

Hur, W. M., Kim, H., \& Woo, J. 2014. How CSR leads to corporate brand equity: Mediating mechanisms of corporate brand credibility and reputation. Journal of Business Ethics, 125: $75-86$. 
Jayawardhena, C., Souchon, A. L., Farrell, A. M., \& Glanville, K. 2007. Outcomes of service encounter quality in a business-to-business context. Industrial Marketing Management, 36: $575-588$.

Kelloway, E.K. 1995. Structural Equation Modelling in perspective. Journal of Organizational Behavior, 16: 215-224.

Kline, R.B. 1998. Principles and Practices of Structural Equation Modelling. New York: The Guildford Press.

Kukar-Kinney, M., \& Grewal, D. 2006. Consumer willingness to claim a price-matching refund: A look into the process. Journal of Business Research, 59: 11-18.

Lam, S.Y., Shankar, V., Erramili, M.K., \& Murthy, B. 2004. Customer value, satisfaction, loyalty, and switching costs: an illustration from a business-to-business service context. Academy of Marketing Science, 32: 293-311.

Loe, T. W., Ferrell, L., \& Mansfield, P. 2000. A review of empirical studies assessing ethical decision making in business. Journal of Business Ethics, 25: 185-204.

Lowengart, O., Mizrahi. S., \& Yosef. R. 2003. Effect of consumer characteristics on optimal reference price. Journal of Revenue and Pricing Management, 2: 201-215.

Lynch, J., \& de Chernatony, L. 2004. The power of emotion: brand communication in business-to-business markets. Journal of Brand Management, 11: 403-419.

Maignan, I. Ferrell, O.C. \& Ferrell, L. 2005. A stakeholder model for implementing social responsibility in marketing. European Journal of Marketing, 39: 956 - 977.

Mazzanti, M., \& Zoboli, R. 2006. Economic instruments and induced innovation: The European policies on end-of-life vehicles. Journal of Ecological Economics, 58: 318 337.

Maas, K., \& Liket, K. 2011. Talk the walk: Measuring the impact of strategic philanthropy. Journal of Business Ethics, 100: 445-464.

Martin, K. D., \& Johnson, J. L. 2010. Ethical beliefs and information asymmetries in supplier relationships. Journal of Public Policy \& Marketing, 29:38-51.

Mulki, J. P., \& Jaramillo, F. 2011. Ethical reputation and value received: customer perceptions. International Journal of Bank Marketing, 29: 358-372.

Melewar, T.C. \& Nguyen, B. 2015. Five areas to advance branding theory and practice, Journal of Brand Management, 21: 758-769.

Melewar, T.C. \& Karaosmanoglu, E. 2006. Seven dimensions of corporate identity: A categorization from the practitioners' perspectives. European Journal of Marketing 40: 846-869. 
Malaysian Industrial Development Authority (MIDA), 2008. Available at: http://www.mida.gov.my/env3/; date accessed: 15 Jan 2014.

McWilliams, A., \& Siegel, D. 2001. Corporate social responsibility: A theory of the firm perspective. Academy of Management Review, 26: 117-127.

Morgan, R. M., \& Hunt, S. D. 1994. The commitment-trust theory of relationship marketing. Journal of Marketing, 58: 20-38.

National Economic Advisory Council (NEAC), 2010. New Economic Model for Malaysia Part 1. Kuala Lumpur: Percetakan Nasional Malaysia Berhad. Available at: http://www.neac.gov.my; date accessed: 25 January 2016.

Nguyen, B., Melewar, T.C., \& Schultz, D. 2016. Asia branding: Connecting brands, consumers and companies (Eds). New York: Palgrave MacMillan.

Nnorom, I.C. \& Osibanjo. O. 2008. Overview of electronic waste (e-waste) management practices and legislations, and their poor applications in the developing countries. Journal of Resources, Conservation and Recycling, 52: 834-858.

Olin, W. 2004. On Brand. USA: Thames \& Hudson.

Olin, W. 2014. Wally Olins Brand New: The shape of brands to come. USA: Thames \& Hudson.

Okoye, A. 2009. Theorising corporate social responsibility as an essentially contested concept: is a definition necessary? Journal of Business Ethics, 89: 613-627.

Page, G., \& Fearn, H. 2005. Corporate reputation: what do consumers really care about? Journal of Advertising Research, 45: 305-313.

Palazzo, G. \& Basu, K. 2007. The ethical backlash of corporate branding. Journal of Business Ethics 73: 333-346

Paluszek, J. (2005). Ethics and Brand Value: Strategic Differentiation (Power Point Slide). Business and Organizational Ethics Partnership Meeting. Markkula Center for Applied Ethics, Santa Clara University. USA, Available at: http://ethicsbranding.com/images/ethics-and-brand-value $\% 20[$ ReadOnly] $\% 20[$ Compatibility\%20Mode].pdf; date accessed: 20 November 2014

Parguel, B., Benoît-Moreau, F., \& Larceneux, F. 2011. How sustainability ratings might deter 'greenwashing': A closer look at ethical corporate communication. Journal of Business Ethics, 102:15-28.

Payne, A. \& Frow, P. 2013. Strategic customer management: Integrating CRM and relationship marketing. Cambridge, UK: Cambridge University Press.

Powell, S. M. 2011. The nexus between ethical corporate marketing, ethical corporate identity and corporate social responsibility: An internal organizational perspective. European Journal of Marketing, 45:1365-1379. 
Preacher, K. J., \& Hayes, A. F. 2004. SPSS and SAS procedures for estimating indirect effects in simple mediation models. Behavior Research Methods, Instruments, \& Computers, 36: 717-731.

Preacher, K. J., \& Hayes, A. F. 2008. Asymptotic and resampling strategies for assessing and comparing indirect effects in multiple mediator models. Behavior Research Methods, 40: 879-891.

Preacher, K. J., \& Kelley, K. 2011. Effect size measures for mediation models: quantitative strategies for communicating indirect effects. Psychological Methods, 16: 93-115.

Roper, S., \& Davies, G. 2007. The corporate brand: Dealing with multiple stakeholders. Journal of Marketing Management, 23:75-90.

Rucker, D. D., Preacher, K. J., Tormala, Z. L., \& Petty, R. E. 2011. Mediation analysis in social psychology: Current practices and new recommendations. Social and Personality Psychology Compass, 5: 359-371.

Sagar, M., Singh, D., \& Agrawal, D. P. 2006. Framework of ethical brand positioning: A case study of anchor. Journal of Management Research, 6: 72-83.

Schwartz, M. S., \& Carroll, A. B. 2003. Corporate social responsibility: A three-domain approach. Business Ethics Quarterly, 13: 503-530.

Sharp, R.R. 2003. Ethical issues in international environmental health research, Environmental Health Perspectives, 111: 1786-1788.

Singh, J. J., Iglesias, O., \& Batista-Foguet, J. M. 2012. Does having an ethical brand matter? The influence of consumer perceived ethicality on trust, affect and loyalty. Journal of Business Ethics, 111: 541-549.

Singh, J., \& Sirdeshmukh, D. 2000. Agency and trust mechanisms in consumer satisfaction and loyalty judgments. Journal of the Academy of Marketing Science, 28: 150-167.

Stahl, B.C. 2005. The responsible company of the future: reflective responsibility in business. Futures, 21: 117-131.

Stanaland, A. J., Lwin, M. O., \& Murphy, P. E. 2011. Consumer perceptions of the antecedents and consequences of corporate social responsibility. Journal of Business Ethics, 102: 47-55.

Story, J., \& Hess, J. 2010. Ethical brand management: customer relationships and ethical duties. Journal of Product \& Brand Management, 19: 240-249.

UNICEF Malaysia, 2009. Corporate social responsibility policies in Malaysia. Available at http://www.unicef.org/malaysia/Unicef_CSR_Msia_110713_lowres.pdf; date accessed: 15 Jan 2016. 
Urde, M. 2003. Core value-based corporate brand building. European Journal of Marketing, 37: 1017-1040.

Urde, M. 2009. Uncovering the corporate brand's core values. Management Decision, 47: 616-638.

Urde, M., Baumgarth, C., \& Merrilees, B. 2013. Brand orientation and market orientationfrom alternatives to synergy. Journal of Business Research, 66: 13-20.

van Riel, C.R.A., Mortanges, C.P.de \& Streukens, S. 2005. Marketing antecedents of industrial brand equity: An empirical investigation in special chemicals. Industrial Marketing Management, 34: 841-847.

van Rekom, J., Go, F. M., \& Calter, D. M. 2014. Communicating a company's positive impact on society - Can plausible explanations secure authenticity? Journal of Business Research, 67(9), 1831-1838.

van de Ven, B. 2008. An ethical framework for the marketing of corporate social responsibility. Journal of Business Ethics, 82: 339-352.

Votaw, D. 1972. Genius becomes rare: A comment on the doctrine of social responsibility Pt. I. California Management Review, 15:25-31.

Wartick, S.L. 2002. Measuring corporate reputation: definition and data. Business and Society, 41: 371- 392.

Whetten, D.A. \& Mackey, A. 2002. A social actor conception of organizational identity and its implications for the study of organizational reputation. Business and Society, 41: 393.

Whysall, P. 2000. Marketing ethics - an overview. The Marketing Review, 1:75-195.

Wilde, S.J., Kelly \& S.J., Scott, D. 2004. An exploratory investigation into e-tail image attributes importance to repeat, internet savvy customers. Journal of Retailing and Consumer Service, 11 (3), 131-139.

Wood, G. (2000). A cross cultural comparison of the contents of codes of ethics: USA, Canada and Australia. Journal of Business Ethics, 25: 287- 298.

Zhao, X., Lynch J.G. Jr. \& Chen, Q. 2010. Reconsidering Baron and Kenny: Myths and truths about mediation analysis. Journal of Consumer Research, 37: 197-206. 
Table 1

Construct, Dimension, Items and CFA standardized loadings

\begin{tabular}{|c|c|c|}
\hline Construct/Dimensions & Item & $\begin{array}{l}\text { CFA - } \\
\text { Standardized } \\
\text { loadings }\end{array}$ \\
\hline Product Quality & Our company considers brand X because of its good performance & 0.71 \\
\hline (7 items) & Our company considers brand $\mathrm{X}$ due to its good features & 0.72 \\
\hline Crosby et al. (2003) & The product specification of brand X matches our needs & 0.76 \\
\hline \multirow[t]{4}{*}{ van Riel et al. (2005) } & Brand $\mathrm{X}$ can last for a long time (durable) & 0.73 \\
\hline & Our company considers brand $\mathrm{X}$ as high quality & 0.71 \\
\hline & Our company considers brand $\mathrm{X}$ to be innovative & 0.77 \\
\hline & * Our company buys brand $\mathrm{X}$ because products of brand $\mathrm{X}$ are aesthetically pleasing & - \\
\hline Service Quality & When staff of brand $\mathrm{X}$ promise to do something by a certain time, they do so & 0.77 \\
\hline (8 items) & When our company has problems, staff of brand $\mathrm{X}$ are sympathetic and reassuring & 0.79 \\
\hline Jayawardhena et al. ( 2007) & We buy brand $\mathrm{X}$ as employees of brand $\mathrm{X}$ are polite & 0.75 \\
\hline \multirow[t]{5}{*}{ van Riel et al. (2005) } & Employees of brand $\mathrm{X}$ give us personal attention & 0.77 \\
\hline & Our company buys brand $\mathrm{X}$ because it provides good online information & 0.72 \\
\hline & Our company buys brand $\mathrm{X}$ because it quickly provides supplementary information & 0.78 \\
\hline & *Our company can trust employees of brand $\mathrm{X}$ & - \\
\hline & *Our company buys brand $\mathrm{X}$ because it provides good information $\&$ documentation & - \\
\hline Perceived Price & Our company expects the overall prices of brand $X$ to be high & 0.74 \\
\hline (5 items) & The higher price of brand $\mathrm{X}$ reflects its quality & 0.66 \\
\hline Bolton et al. (2000) & The price of this brand is acceptable & 0.75 \\
\hline Kukar-Kinney \& Grewal (2006) & * Brand X's prices are likely to be higher than average market prices for the same products & - \\
\hline Lowengart et al. (2003) & *This brand has good price information for every type of product and situation & - \\
\hline \multicolumn{3}{|c|}{$\begin{array}{l}\text { Ethical Branding (12 items) with } 3 \\
\text { dimensions namely:- }\end{array}$} \\
\hline 1. Economic responsibility & Our company considers brand $\mathrm{X}$ contributes to profit maximization & 0.76 \\
\hline Enderle \& Tavis (1998) & The company of brand $\mathrm{X}$ always respects its customers/supplier/us & 0.64 \\
\hline 2. Social responsibility & The company of brand $\mathrm{X}$ always respects the laws and regulation of the country & 0.72 \\
\hline \multirow[t]{3}{*}{ Enderle \& Tavis (1998) } & Our company considers brand X organization's internal policy prevents discrimination & 0.74 \\
\hline & Our company considers brand $\mathrm{X}$ as it respects social customs and cultural heritage & 0.80 \\
\hline & Our company uses brand $\mathrm{X}$ due to its recycling program & 0.77 \\
\hline
\end{tabular}


\begin{tabular}{l}
\hline \hline 3. Environment responsibility \\
Enderle \& Tavis (1998)
\end{tabular}

Nnorom \& Osibanjo (2008)

\section{Company Reputation (6 items)}

Cretu \& Brodie (2007)

\section{Brand Loyalty (6 items)}

Morgan \& Hunt (1994)

Davis (2003)

van Riel et al. (2005)
Our company uses brand $\mathrm{X}$ due to its recovery program (e.g., valuable material)

Our company uses brand $\mathrm{X}$ due to its disposal program (e.g., final disposal)

0.72

Our company considers brand $\mathrm{X}$ preserve jobs and engage in community work

Our company uses brand $\mathrm{X}$ due to its commitment to sustainable development through consuming less natural resources

*We consider using brand $\mathrm{X}$ because the company continually succeeds to increase the wealth of stakeholders

* Our company uses brand $\mathrm{X}$ because the manager of the company monitors the potential negative impacts on the community

Our company considers brand X's company is being a good corporate citizen

Our company uses brand $\mathrm{X}$ because its customer focused

Our company considers brand X company as innovation oriented

Our company considers brand X's company as product driven

*We consider buying brand $\mathrm{X}$ because it is well managed

* Our company decides to buy brand $\mathrm{x}$ because it is a successful company

We care a great deal about the long term relationship with brand $\mathrm{X}$

If asked, we would recommend products of brand $X$

We intend to use products of brand $\mathrm{X}$ again in the future

*We use our maximum effort to maintain the relationship with brand $\mathrm{X}$

*We would do almost anything to keep the relationship with brand $\mathrm{X}$
0.78

0.76

0.73

$-$

Note:

1. All CFA loadings are significant at $\mathrm{p}<.01$

2. * refers to items that were removed during purification at the measurement model. In total, 11 items were dropped from further analyses, as they were either cross loaded with high modification indexes (MI) and/or have large standardized residuals (SR) (>2.58), (Byrne, 2001; Long, 1983). 
Table 2

Zero-order Correlations, Composite reliability and Cronbach Alpha

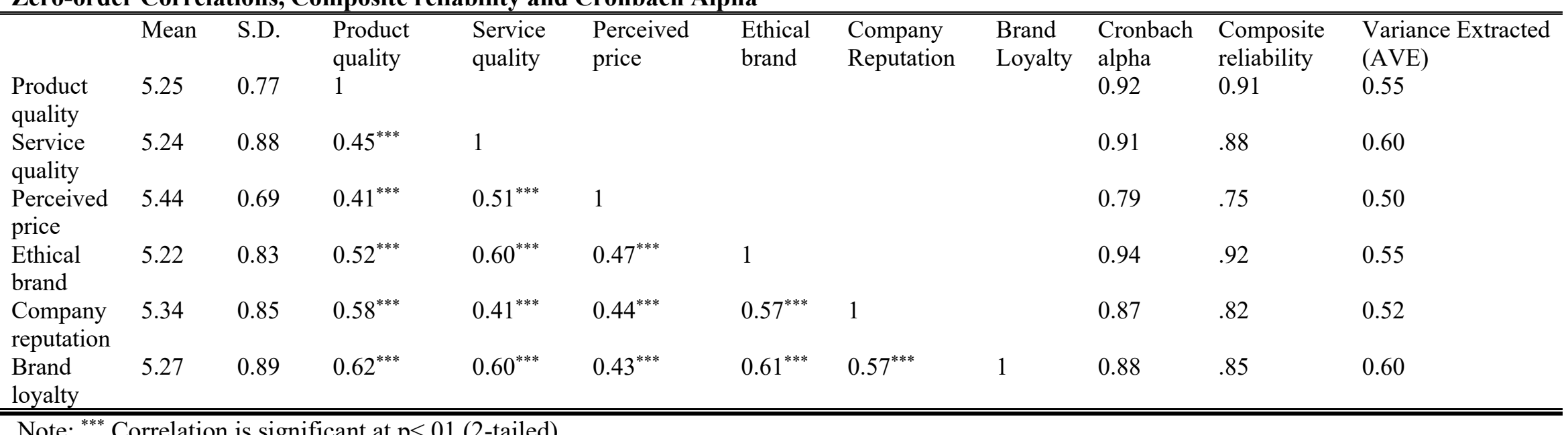

Note: ${ }^{* * *}$ Correlation is significant at $\mathrm{p}<.01$ (2-tailed).

Table 3

Hypothesis Results and Summary for Direct Effects

\begin{tabular}{|c|c|c|c|c|c|}
\hline v & $\boldsymbol{\beta}$ & SE & $\mathbf{C R}$ & $\begin{array}{c}\mathbf{P} \\
\text { Value }\end{array}$ & $\begin{array}{l}\text { Hypothesis } \\
\text { Result }\end{array}$ \\
\hline H1a Product quality $\rightarrow$ Ethical brand & 0.24 & 0.06 & 4.38 & 0.01 & Supported \\
\hline H1b Service quality $\rightarrow$ Ethical brand & 0.43 & 0.05 & 8.68 & 0.01 & Supported \\
\hline H1c Perceived Price $\rightarrow$ Ethical brand & 0.15 & 0.06 & 2.53 & 0.01 & Supported \\
\hline $\mathrm{H} 2 \mathrm{a}$ Product quality $\rightarrow$ Company reputation & 0.46 & 0.06 & 7.59 & 0.01 & Supported \\
\hline $\mathrm{H} 2 \mathrm{~b}$ Service quality $\rightarrow$ Company reputation & 0.01 & 0.06 & 0.19 & 0.85 & Rejected \\
\hline H2c Perceived Price $\rightarrow$ Company reputation & 0.24 & 0.07 & 3.62 & 0.01 & Supported \\
\hline $\mathrm{H} 3 \mathrm{a}$ Product quality $\rightarrow$ Brand loyalty & 0.48 & 0.05 & 8.49 & 0.01 & Supported \\
\hline H3b Service quality $\rightarrow$ Brand loyalty & 0.41 & 0.05 & 7.88 & 0.01 & Supported \\
\hline $\mathrm{H} 3 \mathrm{c}$ Perceived Price $\rightarrow$ Brand loyalty & 0.05 & 0.06 & 0.84 & 0.40 & Rejected \\
\hline
\end{tabular}


Constructs/Hypotheses $\quad \beta$

(Testing indirect effects)
Indirect

effect
SE for

Indirect

effect
Bootstrapping $\quad \mathrm{P}_{\mathrm{M}} \quad$ Completely

results for

indirect effects

$\mathrm{BCa} 95 \% \mathrm{CI}$
Standardized Indirect

Effect on $\mathrm{X}$ to $\mathrm{Y}\left(\mathrm{ab}_{\mathrm{cs}}\right)$
Hypothesis Result\&

Mediation

Conclusion

$\boldsymbol{a}$

B

LL UL

$\beta, a b_{c s}, 95 \%$ CI at both LL \& UL

\begin{tabular}{|c|c|c|c|c|c|c|c|c|c|c|c|}
\hline $\begin{array}{l}\text { H4a Product quality } \rightarrow \text { Ethical } \\
\text { brand } \rightarrow \text { Company reputation }\end{array}$ & $0.50^{* *}$ & $0.39^{* *}$ & $0.61^{* *}$ & $0.41^{* *}$ & $0.19^{* *}$ & 0.05 & 0.12 & 0.30 & 0.32 & $\begin{array}{l}\beta=0.18 ; a b_{c s}=0.19 \\
(95 \% \text { CI } 0.11,0.27)\end{array}$ & $\begin{array}{l}\text { Support for partial } \\
\text { mediation }\end{array}$ \\
\hline $\begin{array}{l}\text { H4b Service quality } \rightarrow \text { Ethical } \\
\text { brand } \rightarrow \text { Company reputation }\end{array}$ & $0.57^{* *}$ & $0.50^{* *}$ & $0.40^{* *}$ & 0.11 & $0.29^{* *}$ & 0.05 & 0.20 & 0.40 & 0.73 & $\begin{array}{l}\beta=0.30 ; \mathrm{ab}_{\mathrm{cs}}=0.28 \\
(95 \% \mathrm{CI} 0.21,0.40)\end{array}$ & $\begin{array}{l}\text { Support for full/ } \\
\text { stronger mediation }\end{array}$ \\
\hline $\begin{array}{l}\text { H4c Perceived Price } \rightarrow \text { Ethical } \\
\text { brand } \rightarrow \text { Company reputation }\end{array}$ & $0.50^{* *}$ & $0.47^{* *}$ & $0.51^{* *}$ & $0.28^{* *}$ & $0.24^{* *}$ & 0.04 & 0.16 & 0.32 & 0.46 & $\begin{array}{l}\beta=0.1950 ; \mathrm{ab}_{\mathrm{cs}}=0.24 \\
(95 \% \text { CI } 0.14,0.27)\end{array}$ & $\begin{array}{l}\text { Support for partial } \\
\text { mediation }\end{array}$ \\
\hline $\begin{array}{l}\text { H5a Product quality } \rightarrow \text { Ethical } \\
\text { brand } \rightarrow \text { Brand loyalty }\end{array}$ & $0.50^{* *}$ & $0.45^{* *}$ & $0.70^{* *}$ & $0.47^{* *}$ & $0.23^{* *}$ & 0.05 & 0.15 & 0.34 & 0.33 & $\begin{array}{l}\beta=0.20 ; a b_{c s}=0.23 \\
(95 \% \text { CI } 0.13,0.28)\end{array}$ & $\begin{array}{l}\text { Support for partial } \\
\text { mediation }\end{array}$ \\
\hline $\begin{array}{l}\text { H5b Service quality } \rightarrow \text { Ethical } \\
\text { brand } \rightarrow \text { Brand loyalty }\end{array}$ & $0.58^{* *}$ & $0.42^{* *}$ & $0.60^{* *}$ & $0.36^{* *}$ & $0.24^{* *}$ & 0.05 & 0.16 & 0.35 & 0.40 & $\begin{array}{l}\beta=0.24 ; \mathrm{ab}_{\mathrm{cs}}=0.24 \\
(95 \% \text { CI } 0.16,0.35)\end{array}$ & $\begin{array}{l}\text { Support for partial } \\
\text { mediation }\end{array}$ \\
\hline $\begin{array}{l}\text { H5c Perceived Price } \rightarrow \text { Ethical } \\
\text { brand } \rightarrow \text { Brand loyalty }\end{array}$ & $0.50^{* *}$ & $0.59^{* *}$ & $0.49^{* *}$ & $0.19^{*}$ & $0.30^{* *}$ & 0.05 & 0.21 & 0.40 & 0.61 & $\begin{array}{l}\beta=0.23 ; \mathrm{ab}_{\mathrm{cs}}=0.30 \\
(95 \% \text { CI } 0.17,0.31)\end{array}$ & $\begin{array}{l}\text { Support for full/ } \\
\text { stronger mediation }\end{array}$ \\
\hline $\begin{array}{l}\text { H6 Ethical brand } \rightarrow \text { Company } \\
\text { reputation } \rightarrow \text { Brand loyalty }\end{array}$ & $0.54^{* *}$ & $0.46^{* *}$ & $0.60^{* *}$ & $0.35^{* *}$ & $0.25^{* *}$ & 0.05 & 0.17 & 0.34 & 0.41 & $\begin{array}{l}\beta=0.23 ; a b_{c s}=0.25 \\
(95 \% \text { CI } 0.16,0.32)\end{array}$ & $\begin{array}{l}\text { Supported for partial } \\
\text { mediation }\end{array}$ \\
\hline
\end{tabular}

Note: $\beta$ - Standardized regression weights for $a, b, c$ and $c$ '; where, path $a$ - IV (X) to mediator (M), path $b$ - M to DV (Y); path $c$ is the total effect; path $c$ ' is the direct effect

$\mathrm{X}$ to Y after controlling for M; SE - Standard Error; All ** indicate $p$ value is significant $=p<.01$ and $*=p<.05$; BCa bias corrected and accelerated; 5000 bootstrap samples, CI confidence Interval, LL lower limit, UL upper limit (PROCESS macro, Preacher and Hayes, 2004; 2008). Further test on mediation is examined through effect sizes: 1. Percent Mediation $\left(\mathrm{P}_{\mathrm{M}}\right)$ and (2) Completely Standardized Indirect Effect on $\mathrm{X}$ to $\mathrm{Y}_{\left(\mathrm{ab}_{\mathrm{cs}}\right)}$ as proposed by (Preacher and Kelly, 2011, see guideline from p. 97 \& 99 , respectively, for formula and calculations) 


\section{AUTHOR BIOGRAPHY}

Sharifah Faridah Syed Alwi, PhD (correspondence author),

Dr. Sharifah Alwi is a Senior Lecturer of Corporate Brand Management and a member of Marketing and Corporate Brand Management Research Group (MCBM) at Brunel Business School in Brunel University London, UK. She received her PhD from Manchester Business School, UK and currently leading a postgraduate program at Brunel - MSc in Applied Corporate Brand Management. Her research interests include branding at product, service and corporate level. She taught mainly modules related to corporate brand management and marketing such as strategic corporate brand consulting, applied corporate brand management and marketing principle. Her work has appeared in several reputable academic journals such as Journal of Business Research, European Journal of Marketing, Industrial Management \& Data Systems and Journal of Brand Management.

\section{Sulaiman Muhammad Ali, PhD}

Dr. Sulaiman Ali is a Lecturer in Marketing in Faculty of Economics and Business, University of Syiah Kuala, in Banda Aceh, Indonesia. He received his PhD from University of Malaya, Malaysia in the area of Ethical Marketing and teaches in the area of business ethics and marketing management. He has over 20 years' experience in teaching and research. His current research interest is ethical and service marketing.

\section{Bang Nguyen, PhD}

Dr. Bang Nguyen, $\mathrm{PhD}$, is a member of the Marketing Department at East China University of Science and Technology (ECUST), School of Business, in Shanghai, China. He is the Editor of The Bottom Line and on the editorial boards of Journal of Marketing Management, Journal of Marketing for Higher Education and Int. Journal of Services, Economics, and Management. His research interests include branding, CRM, services marketing, and innovation management. Bang has published widely in journals such as Industrial Marketing Management, Journal of Business Research, European Journal of Marketing, Journal of Marketing Management, The Service Industries Journal, and Internet Research. 